\title{
Gambaran klinis neuropati pada pasien diabetes melitus di Poliklinik Neurologi RSUP Prof. Dr. R. D. Kandou periode Juli 2014 - Juni 2015
}

\author{
${ }^{1}$ Faisal S Hutapea \\ ${ }^{2}$ Mieke A. H. N. Kembuan. \\ ${ }^{3}$ Junita Maja P. S.
}

\author{
${ }^{1}$ Kandidat Skripsi Fakultas Kedokteran Universitas Sam Ratulangi \\ ${ }^{2}$ Bagian / SMF Neurologi Fakultas Kedokteran Universitas Sam Ratulangi \\ RSUP Prof. Dr. R. D. Kandou Manado \\ Email: faisalhutapea12105@gmail.com
}

\begin{abstract}
Neuropathy is a sensory, motor or mixed disorder of peripheral nerves. This study aimed to describe the clinical picture of neuropathy in patients with diabetes mellitus at the Neurology Clinic of Prof. Dr. R. D. Kandou Hospital Manado. This was a descriptive retrospective study using medical records of patients who came to the Neurology Clinic of Prof. Dr. R. D. Kandou Hospital from July 2014 to June 2015. The results showed that there were 140 diabetes mellitus cases that met the inclusion and exclusion criteria; 83 cases of diabetes mellitus were associated with neuropathy. Neuropathy were most numerous in female patients, age range of 45-65 years, retired profession, and had long-standing diabetes mellitus over 1-5 years. The most common clinical symptom that the patients complained was cramp.
\end{abstract}

Keywords: neuropathy, diabetes mellitus

\begin{abstract}
Abstrak: Neuropati adalah suatu gangguan saraf perifer baik sensorik, motorik atau campuran. Penelitian ini bertujuan untuk mengetahui gambaran klinis neuropati pada pasien diabetes melitus di Poliklinik Saraf RSUP Prof. Dr. R. D. Kandou Manado. Jenis penelitian ini ialah deskriptif retrospektif dengan menggunakan data rekam medik pasien diabetes melitus yang datang ke Poliklinik Saraf RSUP Prof. Dr. R. D. Kandou Manado periode Juli 2014 - Juni 2015. Hasil penelitian memperlihatkan terdapat 140 kasus diabetes melitus yang memenuhi kriteria inklusi dan eksklusi dan 83 kasus diantaranya yang mengalami neuropati. Neuropati paling banyak terdapat pada pasien berjenis kelamin wanita, rentang usia 45-65 tahun, pensiunan, dan telah lama menderita diabetes melitus 1-5 tahun. Gejala klinis yang paling banyak dikeluhkan ialah kram.
\end{abstract}

Kata kunci: neuropati, diabetes melitus

Neuropati perifer adalah suatu gangguan saraf perifer, sensoris, motorik atau campuran yang biasanya simetris dan lebih banyak mengenai bagian distal dari pada proksimal ekstremitas, yaitu yang terjauh dari nukleus saraf. ${ }^{1}$ Gejala neuropati perifer ini juga dapat ditemukan pada pasien diabetes mellitus (DM) yang disebut neuropati diabetik. DM dapat mengakibatkan komplikasi neuropati perifer dalam beberapa bentuk, seperti polineuropati distal simetris, neuropati otonom, dan neuropati akibat jepitan. ${ }^{2}$ Manifestasi klinis neuropati diabetik bisa sangat bervariasi mulai dari tanpa gejala dan hanya bisa terdeteksi dengan pemeriksaan elektrofisiologis, hingga keluhan nyeri hebat. Perasaan nyeri pada nyeri neuropatik bisa muncul secara spontan ataupun setelah ada rangsangan walaupun inadekuat. Gejala nyeri neuropatik dapat bersifat positif (misalnya 
paraestesia dan disestesia), dan dapat pula negatif (hipestesia). ${ }^{3} \quad$ Frekuensi neuropati perifer pada DM cukup tinggi yaitu $57,81 \%$, sebagian besar diantarnya mengidap DM lebih dari 10 tahun (40,54\%). Berdasarkan penelitian epidemiologi, nyeri neuropatik perifer dijumpai pada $16 \%$ pasien diabetes. ${ }^{3}$

Penelitian ini bertujuan untuk mengetahui gambaran klinis neuropati pada pasien Diabetes Melitus di Poliklinik Neurologi RSUP Prof. Dr. R. D. Kandou.

\section{METODE PENELITIAN}

Jenis penelitian ini ialah deskriptif retrospektif dengan menggunakan data rekam medik penderita neuropati diabetik yang datang ke poliklinik Neurologi RSUP Prof. Dr. R. D Kandou Manado periode Juli 2014 sampai Juni 2015.

Kriteria inklusi dari penelitian ini ialah pasien yang datang dan yang berkonsultasi ke Poliklinik Saraf RSUP Prof. Dr. R. D. Kandou Manado periode Juli 2014 sampai Juni 2015, didiagnosis neuropati diabetik oleh dokter spesialis, dan memiliki data yang lengkap sedangkan kriteria eksklusi ialah catatan medik yang tidak dapat diperiksa dan tidak lengkap. Data pasien yang dicatat ialah identitas pasien (nama, jenis kelamin, usia, alamat, pekerjaan) lama menderita DM, diagnosis neuropati, dan gejala klinis yang dialami.

\section{HASIL PENELITIAN}

Dari 140 data rekam medik pasien DM ditemukan 83 pasien yang didiagnosis neuropati diabetik. Jumlah pasien DM yang menderita neuropati lebih banyak dari pada yang tidak mengalami neuropati. Hasil penelitian juga menunjukkan perempuan lebih banyak menderita neuropati dibandingkan laki-laki. Angka kejadian neuropati terbanyak pada kelompok umur 45-65 tahun yaitu sebanyak 60 kasus (72,3\%) (Tabel 1). Pasien yang paling banyak mengalami neuropati ialah pensiunan (39,8\%) (Tabel 2). Dari hasil penelitian yang dilakukan didapatkan bahwa kejadian neuropati terbanyak pada pasien dengan lama menderita DM selama 1-5 tahun yaitu sebanyak 52 orang (Gambar 1) dan gejala klinis terbanyak yang dialami oleh pasien ialah kram (Tabel 3).

Tabel 1. Distribusi Penderita Neuropati Berdasarkan Umur

\begin{tabular}{ccc}
\hline Umur & $\begin{array}{c}\text { Frekuensi } \\
(\mathrm{n})\end{array}$ & $\begin{array}{c}\text { Persentase } \\
(\%)\end{array}$ \\
\hline 20-30 tahun & 0 & 0 \\
31-45 tahun & 5 & 6 \\
46-65 tahun & 60 & 72,3 \\
$>65$ tahun & 18 & 21,7 \\
Total & 83 & 100 \\
\hline
\end{tabular}

Tabel 2. Distribusi Penderita Neuropati Berdasarkan Pekerjaan

\begin{tabular}{lcc}
\hline Pekerjaan & $\begin{array}{c}\text { Frekuensi } \\
(\mathrm{n})\end{array}$ & $\begin{array}{c}\text { Persentase } \\
(\%)\end{array}$ \\
\hline Pensiunan & 33 & 39,8 \\
PNS & 6 & 7,2 \\
Supir & 1 & 1,2 \\
Ibu Rumah Tangga & 29 & 34,9 \\
Pegawai Swasta & 9 & 10,8 \\
Petani & 2 & 2,4 \\
Nelayan & 1 & 1,2 \\
Wiraswasta & 2 & 2,4 \\
Total & 83 & 100 \\
\hline
\end{tabular}

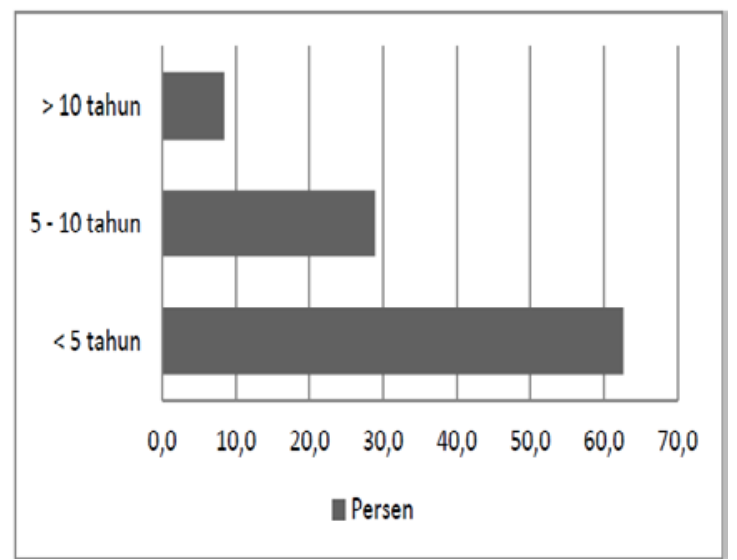

Gambar 1. Distribusi Penderita Neuropati Berdasarkan Lama Menderita DM 
Tabel 3. Distribusi Penderita Neuropati Dengan Kombinasi Gejala Klinis

\begin{tabular}{|c|c|c|c|c|c|c|c|c|}
\hline \multicolumn{9}{|c|}{ Gejala Klinis } \\
\hline \multicolumn{3}{|c|}{4 Gejala Klinis } & \multicolumn{3}{|c|}{3 Gejala Klinis } & \multicolumn{3}{|c|}{2 Gejala Klinis } \\
\hline Kombinasi & $\mathrm{n}$ & $\%$ & Kombinasi & $\mathrm{n}$ & $\%$ & Kombinasi & $\mathrm{n}$ & $\%$ \\
\hline \multirow[t]{6}{*}{ KNTB } & 0 & 100 & KNT & 2 & 100 & KN & 5 & 50 \\
\hline & & & KNB & 0 & & KT & 3 & 30 \\
\hline & & & KTB & 0 & & KB & 2 & 20 \\
\hline & & & NTB & 0 & & NT & 0 & 0 \\
\hline & & & & & & NB & 0 & 0 \\
\hline & & & & & & TB & 0 & 0 \\
\hline Total & 0 & 100 & Total & 2 & 100 & Total & 10 & 100 \\
\hline
\end{tabular}

$\mathrm{K}=\mathrm{Kram}$

$\mathrm{N}=$ Nyeri otot dan nyeri seperti tertusuk

$\mathrm{T}=$ Terasa tebal

$\mathrm{B}=$ Perasaan terbakar atau dingin

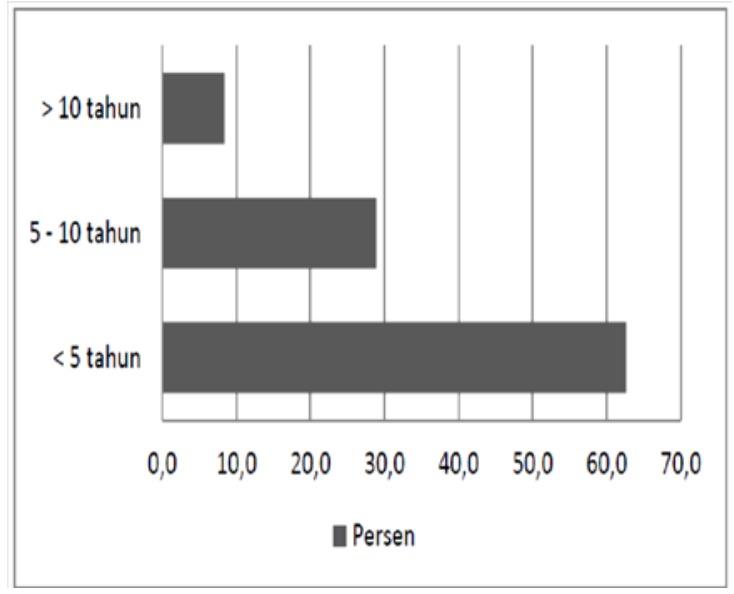

Gambar 1. Distribusi Penderita Neuropati Berdasarkan Lama Menderita DM

\section{BAHASAN}

Berdasarkan hasil penelitian yang dilakukan di RSUP Prof. DR. R. D. Kandou Manado, jumlah penderita diabetes melitus periode Juni 2014 -Jjuli 2015 sebanyak 140 kasus yang sesuai dengan kriteria inklusi dan semuanya merupakan penderita diabetes melitus tipe 2 (DMT2). Dari 140 kasus tersebut ditemukan 83 pasien yang didiagnosis neuropati perifer (59,3\%). The Rochester Neuropathy Study meneliti 278 pasien DMT2 dan mendapatkan 164 pasien (59\%) menderita neuropati perifer. ${ }^{4,5}$

Hasil penelitian ini juga mendapatkan penderita DMT2 berjenis kelamin perempuan lebih banyak yaitu 45 orang (54\%) dibandingkan dengan laki-laki sebanyak 38 orang (46\%). Penelitian SYDNEY menyatakan bahwa jenis kelamin tidak memengaruhi angka kejadian neuropati. ${ }^{6,7}$ Penelitian analitik oleh Darsana $^{8}$ yang dilakukan di RSU Sanglah Denpasar juga mendapatkan bahwa tidak terdapat korelasi bermakna antara jenis kelamin dan angka kejadian neuropati. Hal ini juga ditemukan dalam hasil penelitian yang didapat bahwa perbedaan jumlah penderita neuropati antara laki-laki dan perempuan hanya sedikit yaitu 8\% saja.

Hasil penelitian yang dilakukan menunjukkan bahwa rentang usia yang paling banyak menderita neuropati ialah pada usia 45-65 tahun yaitu sebanyak 60 kasus (72,3\%). Hasil penelitian ini serupa dengan penelitian yang dilakukan oleh Darsana $^{8}$ yaitu penderita neuropati paling banyak terdapat pada rentang usia 45-59 tahun yaitu sebanyak 54 orang (66\%) dari keseluruhan pasien yang diperiksa. Penelitian yang dilakukan Priyantono ${ }^{9}$ di RSUP Dr. Kariadi juga menunjukkan bahwa rentang usia penderita neuropati paling banyak pada usia 45-65 tahun yaitu sebanyak 79 orang (89\%) dari keseluruhan pasien yang diteliti. Banyaknya penderita neuropati pada rentang usia 45-65 tahun ini disebabkan karena usia lanjut berhubungan dengan akumulasi kerusakan akibat radikal bebas seperti peningkatan kadar lipid peroksida dan perubahan aktivitas enzim yang diakhiri dengan kerusakan jaringan 
pada usia lanjut. ${ }^{6}$

Sebagian besar subjek penelitian ialah pensiunan (39,8\%). Hal ini mungkin disebabkan oleh usia yang sudah lanjut dan pasien berdomisili di kota besar. Pekerjaan tidak berhubungan langsung dengan angka kejadian DMT2 dan neuropati, tetapi lebih banyak berkaitan dengan keberadaan penduduk kota yang sebagian besar merupakan penduduk urban yang dihubungkan dengan pola hidup. Pola hidup yang tidak baik dapat meningkatkan resiko timbulnya DMT2 dan neuropati. Penelitian yang dilakukan Darsana ${ }^{8}$ di RSU Sanglah Denpasar memperlihatkan terdapat korelasi bermakna antara lama menderita DMT2 dengan angka kejadian neuropati. Dalam penelitian Azura MS et al. ${ }^{10}$ juga dilaporkan bahwa gejala klinis neuropati akan bertambah seiring bertambahnya umur. Untuk setiap pertambahan umur 1 tahun, maka gejala klinis neuropati akan muncul 1,11 kali pada penderita neuropati dibandingkan dengan yang bukan penderita neuropati. Penelitian oleh Prasetyo ${ }^{6}$ di RSU Semarang juga mendapatkan hasil bahwa lama menderita DMT2juga memengaruhi timbulnya gejala klinis neuropati, yaitu penderita neuropati paling banyak terdapat pada rentang 1-10 tahun menderita DMT2. ${ }^{6}$ Hasil tersebut juga serupa dengan penelitian yang telah dilakukan yaitu penderita neuropati terbanyak ialah pasien dengan lama menderita DMT2 dalam rentang 1-5 tahun yaitu sebanyak 52 orang. Penelitian yang dilakukan di RSUP Prof Dr. R.D. Kandou Manado juga mendapatkan gejala klinis yang paling banyak yaitu gejala klinis kram, yaitu sebanyak 70 orang $(84,3 \%)$ dari keseluruhan pasien. Hasil penelitian ini bersifat subjektif, artinya hasil penelitian hanya bergantung pendapat pasien yang mengalami gejala klinis neuropati tersebut. Karena penelitian yang dilakukan adalah penelitian yang bersifat deskriptif dan retrospektif, untuk menentukan gejala klinis dan tingkat keparahan dari neuropati cukup sulit sehingga diperlukan pemeriksaan diagnostik yang memberikan nilai objektif terhadap gejala klinis yang dialami pasien, seperti skor Diabetic Neuropathy Symptom (DNS) dan Diabetic Neuropathy Examination (DNE). Kedua pemeriksaan ini merupakan sistem skoring yang mengunakan alat yang canggih dengan sensitivitas sebesar 96\% dan spesifisitas sebesar 51\% terhadap diagnosis neuropati. $^{6,11,12}$

\section{SIMPULAN}

Berdasarkan hasil penelitian yang dilakukan di RSUP Prof. Dr. R. D. Kandou dapat disimpulkan bahwa kejadian neuropati paling banyak terdapat pada pasien berjenis kelamin wanita, rentang usia 45-65 tahun, pensiunan, dan telah lama menderita diabetes melitus 1-5 tahun. Gejala klinis yang paling banyak dikeluhkan ialah kram.

\section{DAFTAR PUSTAKA}

1. Rubenstein D, Wayne D, Bradley $J$. Kedokteran klinis [onlin] (6th ed). Jakarta: EGC, 2003 [cited: 2015 Sep 20]. Available from: Googlebooks.

2. Ginsberg L. Neurologi [monograpi online] (8th ed). Jakarta: EGC, 2005 [cited: 2015 Sep 20]. Available from: Googlebooks.

3. Pinzon R. Diagnosis nyeri neuropatik dalam praktik sehari-hari. CDK [serial online]. 2012 [cited: 2015 Sep 20]. Available from:: http://www.kalbemed.com/

4. Sudoyo A.W, Setiyohadi B, Alwi I, Simadibrata M, Setiati S, editors. Ilmu Penyakit Dalam (5th ed). Jakarta: InternaPublishing; p. 1947-9.

5. The Rochester Diabetic Neuropathy Study. Reassessment of test and criteria for diagnosis and stage severity. Neurology, 1992

6. Prasetyo M A. Pengaruh penambahan Alpha Lipoic Acid terhadap perbaikan penderita polineuropati diabetika [Tesis]. Semarang: Universitas Diponegoro; 2011.

7. Ziegler D, Ametov A, Barinov A, Dyck PJ, Gurieva I, Low PA, et al. Oral treatment with alpha lipoic acid improves symptomatic diabetic polyneuropathy. Diabetes care. 2006;29(11):2365-70.

8. Darsana IN. Korelasi positif kadar asam 
urat serum tinggi dengan neuropati diabetik perifer pada penderita DM tipe 2 di Rumah Sakit Umum Sanglah Denpasar [Tesis]. Denpasar: Universitas Udayana; 2014.

9. Priyantono T. Faktor-faktor resiko yang berpengaruh terhadap timbulnya neuropati pada diabetes melitus tipe 2 . [Tesis]. Semarang: Universitas Diponegoro; 2005.

10. Azura MS, Adibah HI, Juwita S. Risk factor of peripheral neuropathy among newly diagnosed type 2 diabetic patients in primary care clinic. International Journal of Collaborative Research on Internal Medicine \& Public Health [serial online]. 2012 [cited: 2015 Sep 20]. Available from: http://internalmedicine.imedpub.com/ri sk-factor-of-peripheral-neuropathyamong-newlydiagnosed-type-2diabetic-patients-in-primarycareclinic.pdf

11. Lumbantobing SM. Neurologi klinik pemeriksaan fisik dan mental (Cetakan 17). Jakarta: Balai Penerbit FKUI, 2014; p, 115-130

12. Yang $\mathbf{Z}$, Chen $\mathbf{R}$, Zhang $\mathbf{Y}$, Huang $\mathbf{Y}$, Hong $\mathbf{T}$, Sun $\mathbf{F}$, et al. Scoring system to screen for diabetic peripheral neuropathy. The Cocharane collaboration. John Wiley \& Sons,Ltd. 2014. Available from: cochranelibrary.com. 